\title{
João Leitão de Abreu, o juiz e a política*
}

\author{
José Néri da Silveira**
}

1. O honroso convite que me formularam os ilustres professores Eduardo Carrion e Plínio de Oliveira Corrêa, respectivamente diretor e vicediretor desta Faculdade, ao ensejo das comemorações de seu centenário, para falar sobre João Leitão de Abreu, o juiz e a política, põe-me, por primeiro, emocionado, diante da escada da saudade. Dela disse Ruy Cirne Lima, inspirado em Mário Quintana: "De poesia é feita a escada de Mário Quintana, à qual tanto se assemelha uma vida que se corta: nem fundamento no chão, nem patamar ao topo. Essa é a escada da saudade, na qual, de algum modo, se retrata o impulso à transcendência e ao infinito, que, todos, escondemos dentro de nós, - o impulso que, a todos, nos une, para além da morte, sempre, dentro da vida". Esse contraste do real que parece suspenso no irreal, e assim com a aparência do nada, desfaz-se, todavia, pelo mistério da fé, ao nos infundir o saber consolador de que a vida não termina com a morte, senão meramente se transforma. Esse conflito interior, que de certo modo sempre nos perturba, aflige-nos mais intensamente, quando a existência que se muda é a vida de um amigo. Tal como sobem as preces, alteiam-se, por essa escada, diante de nós, ao rumo do infinito, épocas, fatos, reminiscências, sentimentos os mais nobres da alma, inclusive o da gratidão, como se

\footnotetext{
* Palestra proferida no Ciclo de Conferências sobre a "Influência da Faculdade de Direito da UFRGS na Política e nas Letras Jurídicas", promovido no período de abril a julho de 1999.

** Ministro do Supremo Tribunal Federal, aposentado; professor convidado da Faculdade de Direito da UFRGS.
} 
envoltos, todos, na flagrância mais pura e delicada das flores, que se cultivam com carinho no mais indevassável recanto do coração.

Bem podeis avaliar, senhor diretor, senhores professores, caríssimos alunos, as reminiscências que este instante me traz, lembrando a extraordinária figura de João Leitão de Abreu, amigo de quase quarenta anos, numa amizade que nunca conheceu rusga ou contrariedade, iniciada em 1953, no antigo Conselho do Serviço Público deste Estado, e consolidada em longa convivência proveniente do exercício do magistério, nesta Faculdade e na Faculdade de Direito da Pontifícia Universidade Católica, nos anos 60, na mesma disciplina de Introdução à Ciência do Direito, sendo ele titular e eu o assistente; do trabalho conjunto na elaboração, que exigiu tempo e longas reflexões, por designação governamental, do projeto de adaptação da Carta sul-riograndense de 1947 ao modelo federal de 1967 e, por último, já em Brasília, na condição de membros do Tribunal Superior Eleitoral, na segunda parte da década de 1970. Quis, por fim, o Senhor de nossas vidas e de nossos destinos, em seus insondáveis desígnios, que houvesse eu, em 1981, de ter assento, no Supremo Tribunal Federal, precisamente, na cátedra que, por sete anos, fora ilustrada e honrada pelo ministro João Leitão de Abreu.

2. Nasceu, a 6 de julho de 1913, João Leitão de Abreu, em Cachoeira do Sul, RS, às margens do rio Jacuí, filho de Jary Carvalho de Abreu e de dona Ana Leitão de Abreu. Desde suas origens, gozou de notabilidade a cidade natal de João Leitão de Abreu, hoje conhecida, carinhosamente, como "Princesa do Jacuí". Terra de escaramuças entre castelhanos e portugueses, no século XVIII; elevada à categoria de vila, com a denominação de Vila Nova de São João da Cachoeira, por alvará de Dom João VI, de 26.4.1819, instalada a 5 de agosto de 1820 , como o sexto município da Capitania de São Pedro; por duas vezes, visitada por Dom Pedro II (1846 e 1865); com ativa participação na Revolução Farroupilha, de 1835 a 1845 , e filhos militares destacados, também, na Guerra do Paraguai. Dela saíram, no século passado e neste, ilustres poetas, jornalistas, políticos, juristas e magistrados. Com tantos vultos eminentes e de longa história, Cachoeira estendeu sua glória até a cúpula do Poder Judiciário brasileiro, com a nomeação de seu ilustre filho e jurista - João Leitão de Abreu - para o cargo de ministro do Supremo Tribunal Federal a 24 de maio de 1974, empossado a 17 de junho do mesmo ano como o $240^{\circ}$ membro do Augusto Tribunal, onde alcançou a VicePresidência, em fevereiro de 1981, havendo, antes, sido, também, ministro do Tribunal Superior Eleitoral (1976), seu vice-presidente, a 7.11.1977, e presidente, eleito em novembro de 1978, sucedendo o saudoso ministro José Geraldo Rodrigues Alckmin. 
3. Atingir o cume do Poder Judiciário, onde as liberdades e os direitos dos cidadãos, a Federação e a República encontram o último reduto de defesa institucional, bem assim exercer eleva-das funções ministeriais no Poder Executivo, não foi, entretanto, jornada sem sacrifícios para João Leitão de Abreu.

De sua formação e da juventude, dá-nos testemunho seguro, por todos os títulos, o ilustre general Aurélio de Lyra Tavares, membro da Academia Brasileira de Letras e seu cunhado, recentemente falecido, em artigo que publicou a 27 de novembro de 1992, no Jornal do Commercio do Rio de Janeiro, referindo-se às homenagens póstumas que foram prestadas a Leitão de Abreu:

O que me parece de maior significação, nessas justas e marcantes homenagens, é que elas exaltam a vida, que eu pude conhecer em passagens muito dificeis, como seu cunhado e amigo, por bem saber que ele se realizou, desde cedo, menino de família pobre, além de numerosa, sem nunca ter tido, por isso mesmo, ensino pago. Ele superou todos os problemas, graças ao interesse e ao desvelo do pai, conseguindo o seu acesso ao Seminário de São Leopoldo. Por falta de vocação, apenas lá ficaria alguns anos, que the foram preciosos, pelo quanto aprendeu, nas matérias que estudou, com grande rendimento do ensino no regime de internato.

Para bem compreender, efetivamente, o ambiente de formação de João Leitão de Abreu, é preciso anotar que o Colégio Conceição de São Leopoldo, fundado em 1869 , sob a orientação dos padres da Companhia de Jesus, representou, na segunda metade do século XIX e até seu fechamento em 1912, a instituição de maior importância na formação dos jovens rio-grandenses, com extraordinário reflexo na cultura gaúcha. Em 3.2.1900, obtinha, como raridade da época, pelo Decreto $n^{\circ}$ 3.580 , "o caráter e os direitos de Ginásio equiparado ao Ginásio Nacional Dom Pedro II do Rio de Janeiro." Por ele passaram alunos que haveriam de ser nomes destacados do episcopado e da política sulinos, como Dom Octaviano Pereira de Albuquerque, Dom João Becker, Dom Vicente Scherer, e os drs. Oswaldo Aranha, Vidal de Oliveira Ramos, Nereu Ramos, João Neves da Fontoura, Vitor e Adolfo Konder, Luiz Englert, Germano Hasslocher e Alberto Pasqualini, dentre tantos outros. Não obstante todos os elogios da época, inclusive da Princesa Isabel e do Conde D'Eu, considerado pelo embaixador da Alemanha, dr. Klaus, estabelecimento "que podia competir com as instituições congêneres da Europa", o Colégio Conceição cerrou as portas, em virtude da Lei Rivadávia, de 5.4.1911, que extinguiu todas as equiparações ao Ginásio Nacional Dom Pedro Il. Dom João Becker, então já à frente da arquidiocese de Porto Alegre, de imediato, entretanto, com extraordinária visão e inspiração, confiou aos Jesuítas do Conceição, a educação e a instrução dos seminaristas, tanto do clero regular, 
como do clero secular, da Arquidiocese. E a 20 de maio de 1913, em lugar do histórico Colégio Conceição, quase sem solução de continuidade e guardando o mesmo espírito, surge o Seminário Provincial de São Leopoldo, para onde afluíram, de todas as dioceses do Estado, jovens destinados à preparação para o sacramento da ordem, quer no Seminário Menor, para os cursos ginasial e colegial, quer no Seminário Maior, como estudantes de Filosofia e Teologia.

Foi em ambiente de internato qual esse, - de rígida disciplina, de reflexão, de cursos ministrados com a seriedade que tanto caracteriza os jesuítas como educadores, no estudo de latim, grego, alemão, inglês e francês, história, filosofia e religião, dentre outras matérias -, que o então jovem João Leitão de Abreu iniciou e, por alguns anos, desenvolveu sua formação humanística, filosófica e literária, de tão acentuada influência em sua ação como pensador, juiz e político.

Permanecendo em Cachoeira do Sul, aí exerceu o jornalismo, como anotou Lyra Tavares, ao escrever: "Recordo-me, sempre, das noitadas na redação do Jornal do Povo, fundado pelo seu avô, Virgílio Carvalho de Abreu, onde eu o acompanhava, todas as quartas e sábados, durante o preparo das edições das quintas-feiras e domingos". Segundo os registros, por volta de 1930 , tornou-se redator do Jornal do Povo. E, ainda, testemunha o ilustre general Lyra Tavares: "Aos dezoito anos, ele prestou o serviço militar no Tiro de Guerra 254 de
Cachoeira do Sul, onde soube escolher e cultivar boas amizades, entre as quais eu partilhava, especialmente, a do advogado Orlando da Cunha Carlos". Desde jovem, portanto, João Leitão de Abreu foi atento aos problemas políticos e sociais e aos debates ideológicos de sua época. Da atuação como redator do Jornal do Povo de sua terra, resultou-lhe, certa feita, inclusive, detenção pela polícia política do início do Estado Novo.

4. Transferindo-se para Porto Alegre, na década de 1940, ingressa João Leitão de Abreu, por concurso público, no serviço estadual, exercendo, aí, relevantes funções, como as de técnico de administração do Departamento do Serviço Público, em 1946; de diretorgeral da Secretaria de Educação e Cultura, quando dessa Pasta era titular o então deputado Eloy José da Rocha, em 1947; e a partir de 5 de maio 1949, por concurso público, tornou-se um dos cinco Conselheiros do Departamento do Serviço Público, depois, Conselho do Serviço Público, onde alcançou merecido e justo renome como administrativista, pelo brilho de suas produções, consubstanciadas em doutíssimos pareceres que emitia no exercício de tão importante múnus, até hoje fonte de indispensável e preciosa consulta, quais magníficos repositórios doutrinários, aos que se dedicam aos estudos jurídicoadministrativos.

De outra parte, havendo colado grau como bacharel em Ciências Jurídicas e Sociais, em 1946, nesta Faculdade, já 
no ano seguinte, com a advocacia, passou a desempenhar, em caráter voluntário, atividade de auxiliar de ensino, junto à cadeira de Direito Administrativo e Ciência da Administração, da mesma Faculdade, sendo regularmente admitido, em 1949, nessa função docente, estando a cátedra então provida pelo hoje também inolvidável professor Ruy Cirne Lima. professor de Direito Administrativo, na Faculdade de Direito da Pontifícia Universidade Católica do Rio Grande do Sul, desde 1952, ao vagar a cátedra de Introdução à Ciência do Direito, nesta Faculdade, veio a ser, nela, investido, a $1^{\circ}$ de março de 1954, concorrendo, posteriormente, ao provimento definitivo, com a tese " $\mathrm{A}$ Validade da Ordem Jurídica", escrita no início de 1964. Em 1955, assumiu a mesma disciplina na Faculdade de Direito da Universidade Pontifícia. De ambas tornou-se professor titular. Membro do Instituto de Administração da Universidade Federal do Rio Grande do Sul, em 1960, passou a dirigir o Instituto de Interpretação Emílio Betti, desta Faculdade de Direito, em 1962. Desse período são dois esplêndidos trabalhos doutrinários: A Discrição Administrativa (1949), com o qual conquistou o Prêmio Alcides Cruz, e $D a$ Prescrição em Direito Administrativo (1961). Da mesma época, é sua publicação sobre Função Social do Imposto.

5. Foi, entretanto, em momento de grave crise na política rio-grandense, em 1964, que o governador Ildo Meneghetti, recompondo o secretariado, convidou o então Conselheiro e professor João Leitão de Abreu, num apelo que se fez irrecusável a seu espírito de serviço à causa pública, para a chefia da Casa Civil do Governo do Estado, ao mesmo tempo em que o professor Ruy Cirne Lima ocupava a Secretaria da Fazenda e o então deputado e professor Paulo Brossard de Souza Pinto assumia a Secretaria do Interior e Justiça. Não tardou e nova função de índole política, já agora no âmbito federal, era confiada ao ilustre jurista. Investido no cargo de ministro da Justiça o senador gaúcho e professor desta Faculdade, dr. Mem de Sá, em 1966, veio a exercer Leitão de Abreu as funções de chefe de Gabinete daquela pasta. Retornando ao Estado, o novo governador, ao assumir em 1967 , convida o professor João Leitão de Abreu a integrar a Comissão designada pelo chefe do Poder Executivo para elaborar o projeto de adaptação da Constituição do Estado do Rio Grande do Sul, nos termos do art. 188 da Carta Federal de 1967. Vencidos os longos debates que então se travaram, no seio da Comissão, como relator do projeto, apresentou trabalho, acompanhado de "exposição de motivos", que constituem peças primorosas, pela técnica e precisão de conceitos, as quais foram levadas ao conhecimento do Supremo Tribunal Federal, na representação do procurador-geral da República Décio Miranda, contra dezenas de dispositivos da Carta gaúcha adaptada, eis que pretendeu elaborá-la, diferentemente, a Assembléia Legislativa, ensejando a 
reação do chefe do Executivo, em trabalho de rico conteúdo doutrinário, da lavra, ainda uma vez, do advogado João Leitão de Abreu (Rp 749-RS).

Convidado a assumir as elevadas funções de ministro de Estado para os Assuntos do Gabinete Civil da Presidência da República, em outubro de 1969, o professor João Leitão de Abreu dirigiu-se, pela derradeira vez, a seus alunos de Introdução à Ciência do Direito, em ambas as Faculdades de Porto Alegre, onde brilhantemente professava, com uma mensagem, - bem o recordo, embora quase trinta anos passados -, que traduzia a grandeza d'alma de um mestre autêntico, cujas palavras brotavam do íntimo do coração, mas os olhos tinham já a expressão da saudade. Era, em verdade, uma despedida, que a todos emocionou, e os fatos definitivamente confirmaram-na.

6. Vocação de pensador, vocação de jurista, com domínio seguro do direito e de sua técnica, inteligência ágil, percuciente, arquitetônica e luminosa na compreensão dos problemas humanos e sociais, espírito capaz de vislumbrar, ao primeiro intuito, o aspecto essencial das questões, energia inquebrantável, servo fidelíssimo do dever, coração em que pulsava o amor perene do justo, enfim, sacerdote de todas as virtudes, assim sempre foi João Leitão de Abreu, no Rio Grande como no Supremo Tribunal Federal, no Tribunal Superior Eleitoral como nos mais altos Conselhos da República. Em dois períodos, na condição de chefe do Gabinete Civil da Presidência da República (de 30.10.1969 a 15.3.1974, no governo do presidente Emílio Médici, e de 12.8.1981 a 15.3.1985, no governo do presidente João Figueiredo), em momentos difíceis da vida política nacional, marcante foi sua atuação de homem público austero, integro, respeitado, lúcido, coordenador eficiente e atento dos atos de governo e permanentemente preocupado com os exclusivos e superiores interesses da Pátria.

A ação de João Leitão de Abreu, em todos os cargos exercidos, no Governo como na Magistratura, guardou fidelidade constante às linhas fundamentais de seu pensamento formado nas fontes mais puras do humanismo cristão.

7. Assim, ao proferir a aula magna da Universidade Federal do Rio de Janeiro, em março de 1973, quando exercia as funções de ministro de Estado para os Assuntos da Casa Civil da Presidência da República, teve ensejo de afirmar:

Na idéia da suma importância que, na ordem espiritual, se assina ao homem, no postulado da sua eminente dignidade, no principio da sua vinculação a comandos éticos de caráter superior, imperativos inextirpáveis do seu ser, nesses velhos dogmas, cuja força magnética se conserva integra, está ainda, porém, ofundamento em que hão de assentar os esforços para restaurar a paz no inquieto coração do homeme suscitar, na ordem social, a harmonia de que se há mister. Argüições graves e 
veementes se levantam, por certo, de todos os lados, aos padrões de comportamento ético da humanidade, pregando-se, para corrigi-los, a necessidade de ampla revolução espiritual. Essas increpações nãose dirigem, porém, no fundo, à inteligência ética ou à correção dos cânones morais, porém à própria alma humana, que, na sua fraqueza, no seu egoismo, enfim, na avidez dos seus apetites, continua, como ainda hoje diria São Paulo, a não fazer o bem que quer e a fazer o mal que não quer. O descumprimento da regra ética não lhe retira, porém, a validade que permanece integra na sua retidão, ainda que a desobediencia seja total e permanente, ainda que a rebeldia seja deste, daquele ou de todos os sujeitos morais. Diz-se, a esse respeito, que o Sermão da Montanha não perderia, como lei moral, a sua validade inabalável, ainda que jamais tivesse sido cumprido.

Em escrito vindo a lume em março de 1968, sob o título A Guerra Perpétua, depois de analisar com acuidade os diversos aspectos do estado, atual ou iminente, de beligerância entre os povos e as tentativas frustradas, até agora, de sua superação, bem assim os extraordinários progressos científicos do homem na conquista do mundo sideral, em contraste com a estacionária situação no plano dos comportamentos éticos, anota, sempre no rumo de um humanismo autêntico:

O problema da paz não se prenuncia, por conseguinte, como solucionável em termos simplesmente racionais.
A impotência das construções lógicas ou teóricas para exercer, no universo político-social, o seu império sobre a ordem prática está, contudo, em violento contraste com a miraculosa leficácia para elas reveladas no que concerne ao dominio da natureza. Para vencer, pois, o impulso vital, ou seja, a lei do seu comportamento instintivo, necessita o homem, de acordo com a lição bergsoniana, realizar um salto para fora da natureza, pois que somente assim poderá chegar ao amor da humanidade, sem o qual se construirá sobre a areia o castelo da paz. Embora lesse milagre só se repute factivel pela via sobrenatural da caridade, o certo é que no momento em que o homem, deixando de ser prisioneiro da terra, assume, por obra da ciência, o status de cidadão do universo, deve ele encontrar, nesse feito, especial estímulo para intentar o prodigio de superar-se também no que diz respeito ao comportamento ético, sacudindo de si as cadeias da legalidade natural, a fim de criar condições para que em cada coração pulse a virtude unitiva do amor por.quantos possuem rosto humano.

Não foi diferente seu discurso, em O Gosto Impetuoso da Justiça, em 1979, quando escreveu:

Se a batalha da inteligência tem que ser vencida, não o será, pois, somente com o saber teórico, unicamente com o saber teórico, simplesmente com o saber geral, sistemático ou arquitetônico, porém com tudo isso acrescido de outro saber, o saber pensar, isto é, com a sagesse, que todos preconizam, com a sabedoria. Não apenas, contudo, como acentua Miguel Reale, lebrando Dante, com a sabedoria, mas 
com o uso amoroso da sabedoria, uno amoroso uso di sapienza. Aprofundando a sentença dantesca, o nosso grande pensador juridico sublinha que l'uso amoroso de que ai se fala, não é o amor abstrato, mas o amor concreto da habitualidade. Quando Dante, logo após, define o direito como o uso amoroso da justiça, sublinha Miguel Reale que o poeta não se refere à iustiça como algo estático e simétrico, mas à justiça como exigência de ação, a todo o instante e a toda a hora, à iustiça como presença do próximo, considerado este, não como abstração longínqua, mas como concreção da mão que está perto de nós, mão para a qual nós estendemos a nossa.

\section{E prossegue:}

Não basta, por conseguinte, prestar homenagem verbal à justiça exaltandolhe o esplendor conceitual. É possivel que, sob essa perspectiva tenha, também, a face mais bela do que a estrela da manhã. Porém é na justiça concreta, atuante, viva, fecunda, eficaz, que está, juntamente com o mistério dessa virtude peregrina, a sua autêntica beleza. Não é, portanto, somente como ser de razão que a justiça pode servir ao estabelecimento da paz social e politica, mas principalmente, como sentimento indefinivel e irrefreável que, brotando do mais intimo da alma humana, é capaz de inculcar em cada um, como já dizia, no alvorecer do século, Winston Churchill, falando como Home Secretary, a crença inabalável de que, no coração de cada homem, existe um tesouro.

Noutra oportunidade, discorrendo, ainda, sobre a justiça, observou:
Não é, no entanto, por defeito de limpidez conceitual que a idéia do iusto deixa de implantar-se na sociedade por forma satisfatória, a fim de proporcionar a felicidade, hoje não unicamente sonhada, mas exigida com veemência crescente. Não é, na verdade, porque a noção da justiça se mostra indeter-minada ou indefinida que a sua aplicação à realidade social se torna insegura ou claudicante.

$O$ defeito de perfeição que se vislumbra no justo não provém, pois, necessariamente, do seu conceito, mas dos defeitos imanentes aos passos do agir humano, quando viciados pelo imperialismo truculento dos interesses indivi-duais. A imperfeição, no que respeita à justiça, não será sempre, assim, de sua idéia, porém do sistema positivo que se constrói a sombra dessa noção peregrina, ou da forma pela qual esse complexo normativo pode vir a aplicar-se.

Sobre o mesmo tema, eterno e inexcedível, em discurso a bacharelandos, acentuou o ministro Leitão de Abreu:

Para bem cumprirdes a vossa missão, é impreterivel tenhais aquilo que já se chamou o gosto impetuoso da iustiça, que, no entanto, só se tornará operante, plenamente operante, se vos dispuserdes a seguir, com intransigência, a palavra de Camus, segundo a qual cumpre sejamos justos nós mesmos, se quisermos instituições iustas. Não percais, além disso, por um momento sequer, a consciencia, assim do peso de vossa responsabilidade, como da imensidão da vossa força, na condição de oficiantes do justo, porquanto, se é certo, como proclama 
orador norte-americano, que um homem com Deus é maioria, menos verdade não será que um homem com a justiça é igualmente a maioria.

8. A admirável fidelidade de João Leitão de Abreu aos princípios de formação humanística manifesta-se, quer em sua visão da justiça, quer em sua compreensão do fenômeno político. Ao assumir, pela segunda vez, a chefia do Gabinete Civil da Presidência da República, em agosto de 1981, no discurso de posse, referindo-se à crise que assoberba o mundo de hoje, afirmou:

Essa crise, entretanto, somente seria incontornável, se os homens tivessem perdido a capacidade de pensar de modo novo e de agir também de modo novo, à maneira de que, vai para cerca de um século, luminosamente preconizava Lincoln.

Haveria, em outras palavras, razões para medo, medo pânico, se os anos de pensamento criativo também houvessem acabado, se a razão, notadamente a razão vital, tivesse caido em letargo. A verdade, no entanto, a feliz verdade, é que assim como, segundo a lição bíblica, o ouvido não se cansa de ouvir e o olho não se cansa de ver, assim também o pensamento não se cansa de pensar. Mas, salvadoramente, não se cansa de pensar também um pensamento inovador, aquele pensamento que, na ordem especulativa, transforma as grandes concepções do mundo e do homem; no plano cientifico, aprofunda e alarga o conhecimento da natureza; na esfera da atividade prática, resolve os problemas vitais e soluciona as questões sociais e políticas.

Malgrado, pois, as turbulências, de caráter por assim dizer cósmico, que assolam o mundo moderno, não será exagero dizer que a humanidade possui imenso cabedal de recursos, de natureza intelectual, para vencer as dificuldades da hora presente. Se vivemos assim, como se tem observado, numa época social rápida, de crises, numa época de esperanças e de grandeza. Maior seria essa esperança, certamente, se a inteligência moral e política acompanhasse os progressos da inteligência especulativa, científica e técnica. É inegável, porém, que, não obstante a debilidade ainda denotada pela inteligência prática, a sociedade faz uso, em grau cada vez maior, daquilo que já se chamou uma das maiores descobertas da humanidade, ou seja, a descoberta, na ordem política e social, do compromisso.'

Nessa linha, em 1984, escreveu:

Não é de hoje que as idéias governam o mundo. Porém, jamais o seu poder foi tamanho como hoje. As idéias, que comandam a história, não são de muitos, nem são puramente politicas. Porquanto as idéias políticas, ao menos as fundamentais, provêm de achados filosóficos. Donde concluir um dos maiores pensadores jurídicos da nossa época que a luta partidária representa ao mesmo tempo uma grande discussão filosófica e que as grandes mudanças políticas são

1 Correio Brasiliense, 13 ago. 1981, p. 4. 
preparadas ou acompanhadas pela filosofia do direito. Daí apregoar, em termos categóricos: No princípio era a filosofia do direito; no fim, a revolução.

Agente da filosofia, a politica aumenta de importância. A tal ponto que se atribui a Jaspers considerar as questóes politicas demasiado sérias para serem deixadas somente aos politicos - juizo que aumenta a responsabilidade do politico, na medida em que lhe pede engenho de certo modo universal. ${ }^{2}$

9. Revelando, ainda uma vez, sua visão humanística da realidade jurídica, que não se pode entender como um mero universo de normatividade positiva ou como um conjunto de construções simplesmente normológicas, João Leitão de Abreu, em 1965, em ensaio sobre A Função Política do Judiciário, observou:

A beleza arquitetônica das construções e o prazer estético das elegâncias teóricas, doutrinárias ou hermenêticas não podem, de maneira alguma, levar o juiz a esquecer o caráter prático ou político da sua função. Se perdesse de vista os fins pragmáticos, a que o seu oficio deve servir, para deixar-se hipnotizar pela contemplação das estruturas lógicas do direito, reproduzir-se-ia, em relação ao juiz, aquilo que Wells, em um dos seus contos, narra de um principe indu. Morrendo-lhe, mordida de serpente, a mulher que adorava, consagrou ele a vida a construir-lhe um monumento, que, sob a denominação de "Pérola do Amor", pretendia fosse o mais belo do mundo. Todo feito de mármore puro, elevam-se em torno do sarcófago, pendendo da abóbada, que o recobria, jóias raras e preciosas. Ao cabo de anos, comple-tando-se, enfim, o monumento, con-templou-o o príncipe com satisfação. $O$ orgulho que experimentava pela beleza suprema do templo fez que sentisse haver ali algo, de somenos importância, que rompia o equilibrio artístico da sua criação. Repentinamente tomou consciência de que a pequena coisa em desarmonia com o desenho não era senão o próprio sarcófago, onde jazia o corpo da bemamada. Não tendo mão em si, voltouse, então, para os ope-rários e, apontando para o sarcófago, bradou: "Levem isto daqui".

Referindo-se, nesse sentido, em fevereiro de 1979, na posse do ministro Antônio Neder, na Presidência do STF, às repercussões das profundas mudanças que se operam, "irreprimível e perturbadoramente", na estrutura da sociedade e nas feições do Estado, notadamente, a partir da Segunda Guerra que assolou o mundo, Leitão de Abreu, ao examinar esse grave tema, no âmbito do cosmo jurídico, assevera que um dos característicos do nosso tempo está em que o direito, pela primeira vez, participa da angústia histórica, explicando:

Manifestação veemente dessa angústia é o processo que se move, em

2 Jornal do Brasil, 23 set. 1984, p. 5. 
todos os quadrantes, contra os chamados métodos ou elementos de interpretação. A tônica desse trabalho critico consiste, de um lado, em que a lei é importante para criar ou revelar todo o direito; de outro, que ao juiz cabe participar, em grau eminente, quando menos, no descobrimento do juridico. A um pensar cerrado, lógico-formal, silogístico, conceitual, agrilhoado ao direito objetivo, opõe-se - teórica, complementar e praticamente -, o pensamento aberto, a análise das questões de direito como problemas que, na sua peculiaridade, requerem o tratamento devido, em nome da iustiça, ao homem vivo, o homem concreto, mergulhado na solidão existencial. A regra de direito é formulada, portanto, em principio, dentro de certa margem de possibilidade, com pretensóes de probabilidade e não de modo exato, matematizante. Funda-se a lei em juizos de valor, que não estão reservados, contudo, exclusivamente, à autoridade legislativa, porquanto a função estimativa ou axiológica penetra e empapa todos os graus de produção do direito. Logo, o processo de individualização ou concretização da norma, se não exclui a dedução lógica, não se esgota em operações dessa natureza. No tocante à interpretação, será necessariamente, no que concerne à lei, um discurso sobre um discurso; porém, um discurso cuja inteligência é fixada, de modo terminante, na ordem judicial, pela sensibilidade ou inspiração individual do intérprete. Exprime-se essa idéia, quando, em direito continental europeu, se ensina que o problema medular da jurisprudência não é a correção formal das deduções, porém a prudente eleição das premissas, operação que não é regida pela lógica formal, mas por juizos de valor. Não intimidam, também, nos Estados Unidos, as regras da lógica, onde um dos maiores dos seus constitucionalistas assevera não haver razão para temê-las, uma vez que o tribunal pode escolher as premissas do silogismo judicial.

Aludindo, pouco tempo depois, ao universo do magistrado como região constantemente visitada pela angústia, em homenagem da Corte, ao ministro Bilac Pinto, acentuou Leitão de Abreu:

Plácido e tranqüilo seria o mundo do magistrado se fosse ele sempre a oficina silenciosa das construções silogísticas. Para isso, fora necessário, porém, que a norma juridica saísse perfeita, completa, acabada, sem falhas ou imprecisões das mãos do legislador, que, onisciente, tudo previsse, tudo deixasse precisa e exatamente disciplinado. Obra humana, à lei se aplica, entretanto, de certa forma, aquilo que do mundo humano, em termos gerais, se diz, ou seja, que nele nada começa jamais absolutamente $e$ nada jamais se completa. A formação do direito pelo legislador não exaure ou tranca, portanto, o processo da sua criação, que prossegue, forçosa e inevitavelmente, pelo trabalho iudiciário. Como a lei deve exprimir, qualquer que seja o processo de sua elaboração, exigência popular, vivana consciência da coletividade, o intérprete do comando legislativo há de buscar, na realidade social, que deu nascimento à norma jurídica, 
elementos para, por via hermenêtica, desenvolver-lhe o sentido.

O tema da angústia no mundo do direito, Leitão de Abreu retoma-o em trabalho que publicou no Jornal do Brasil, edição de 23.9.1984, sobre o mestre de todos nós, Ruy Cirne Lima, logo após a sua morte:

Dominando a ciência jurídica Ruy Cirne Lima conhecia o mundo do direito como poucos. Jurisconsulto acabado, conhecedor emérito dos direitos, comum e canônico, à maneira dos mestres germânicos não se deixava envolver inteiramente pelo complexo normativo, pelos ditados das fontes do direito positivo. Admitia que, pela primeira vez, o direito participava do drama humano, da angústia histórica. Entendia, porém, que isso era exato somente em relação ao direito positivo. Porque a angústia iurídica sempre acompanhou os que, como ele, postu-lavam a existência de um direito su-perior, suprapositivo. Neste se encon-trava para ele a pedra de toque pela qual cumpria aferir a legitimidade do direito humano, bem como a fonte de inspiração para modelar ou corrigir o direito empírico.

Depois de registrar, nessa linha, com ênfase, que a atividade jurisdicional não se pode reduzir a mera atividade jurídica, emparedado o juiz nos limites da lógica formal, esgotando-se a jurisdictio em simples reverências aos enunciados da lei, anota:

Como acontece, porém, com outras espécies de veneração, a que assim se presta à lei lhe é devotada apenas em efigie, por isso que, na realidade, os seus ministros, no exercicio legítimo da sua função, nunca se cingiram, no aplicá-la, a realizar operações de caráter simplesmente lógico-formal. A verdade é que, em todos os tempos, o juiz, para dar resposta às exigências da utilidade comum, sempre se deixou guiar por juizos de valor. Auscultando, em face da dramaticidade inerente ao caso concreto, as pulsações da vida social, o juiz, guardando as palavras da lei, presta-se com certa margem de liberdade na sua aplicação. A índole política da função judiciária não se acusa, via de regra, em períodos de estabilidade, nos quais a lei não se haja divorciado, quanto à sua ratio, das correntes políticas, em cujo seio o con-teúdo legislativo germinou e adquiriu forma. Nos periodos de crise, porém, durante os quais se infiltram no sistema jurídico, sob a pressão ou da algazarra das ruas, ou de nova filosofia politico-social, princípios novos, cria-se, para o órgão judiciário, a melindrosa tarefa de conciliar o passado com o presente, sem infidelidade ao seu nobre mister.

Ressalta desses excertos do pensamento de João Leitão de Abreu correspondência pontual a uma verdade que deve estar, de forma constante, na consciência do magistrado, de qualquer grau: o juiz, como órgão de um dos poderes do Estado, há de ter presente o caráter prático do grave ofício de julgar e, desse modo, embora seguro, como se faz mister, nos exercícios lógico-formais, nas construções teóricas e nas doutrinas hermenêuticas, importa, 
entretanto, não expor suas decisões, em nenhum momento, ao perigo da ausência do real, certo de ser na perspectiva desse, que cabe desenvolver o raciocínio judiciário, orientado, permanentemente, por fatores de índole axiológica e atento, em cada tempo, às exigências do bem comum que lhe incumbe também construir.

10. Em seus trabalhos, acerca da Juris-prudência, aqui entendida na acepção de "ciência do direito positivo", e da Filosofia do Direito, - a partir de precisa discriminação metodológica -, João Leitão de Abreu tratou do fenômeno jurídico, com nítida distinção do que compõe o objeto da ciência do direito positivo e o que se constitui no ofício da especulação filosófica, embora os dois domínios acabem por convergir no entendimento unitário do direito.

$\mathrm{Na}$ visualização, destarte, da universalidade do direito, anota o ministro Leitão de Abreu, em sua obra A Validade da Ordem Jurídica:

5. A validade do direito é, assim, problema que se pode propor segundo critérios diferentes. Tantos serão esses critérios, quantos ângulos pelos quais se possa considerar o fenômeno jurídico.

Posto que seja possivel arrolar série numerosa de critérios, que presidem ao exame do direito, o certo é, contudo, que, desprezadas particularidades secundárias de cada um, podem eles ser reduzidos, na sua substância, a três posições fundamentais: a lógicaformal, a sociológica e a filosófica. Essa tripartição é tradicional, achando-se consagrada, senão explicita, ao menos implicitamente, na maneira como são versados, em geral, os problemas jurídicos.

Negando aceitação à doutrina segundo a qual a validade do direito é noção só aplicável a estruturas normativas, porque traz como consequiência "admitir como só objeto possível do conhecimento jurídico conjunto de normas", "que se reputem válidas", circunscrevendo-se, destarte, a tarefa do juris-ta "à execução de operações lógico-formais a respeito do complexo normativo", anota o ministro Leitão de Abreu:

Não é bastante, contudo, no concernente ao direito positivo, que as normas se tenham formado de acordo com os critérios estabelecidos no ordenamento a que pertencem. É necessário, ainda, que este, em certa medida, corresponda aos comportamentos reais dos individuos. Requerse, por isso, o que se chama de tensão entre a ordem jurídica e os próprios fatos ou realidade social, de tal sorte que haja um mínimo de conformidade entre o sistema normativo e os comportamentos adotados em razão dele.

Em página magistral acerca dos limites do conhecimento científico do direito e da ação do jurista, em sua obra básica, escreveu:

Ainda que se não aceite, integralmente, a tese kelseniana de que a ciencia do direito se exaure no conhecimento das normas, que compõem o direito positivo ou na 
descrição do processo pelo qual estas se engendram, cumpre se reconheça que a atividade científica do jurista não pode prescindir da consideração de normas que já se achem em vigor. Não estão essas normas desligadas, por certo, da realidade social, achando-se, ao revés, em conexão incindivel com esta. É imperioso, desta sorte, que, no exame cientifico do direito, se atente, a um tempo, para o complexo normativo e para os comportamentos sociais a que o sistema jurídico se refere. Quando a atenção recai, não pode esta, de outra parte, enquanto objeto da ciência do direito, deixar de ser referida ao conjunto normológico, consistente nas proposições jurídicas em vigor.

Questão melindrosa é a que entende com a determinação do nexo entre o sistema normativo e os elementos que a ele, indissoluvelmente, estão ligados. Entre as soluções que se apontam para o problema, figura a da teoria dialética, segundo a qual a relação entre a norma e a realidade social é nexo de implicação, estabelecido de tal sorte que não se poderia conceber uma sem a outra. As teorias, se assim se pode dizer, dimensionalistas do direito nele discernem diversos momentos que, por abstração, podem ser vistos na sua individualidade própria, mas que, para se integra-rem no conhecimento iurídico, se relacionam entre si polar ou dialetica-mente, formando o todo sobre o qual incide a atividade cognitiva do jurisconsulto.

Depois de aludir, entre nós, nesse sentido, o pensamento de Miguel Reale, para quem o direito se apresenta sob estrutura tridimensional, decorrente da integração nele, em moldes dialéticos, de norma, fato e valor, acrescenta João Leitão de Abreu:

Malgrado as reservas que ai se enunciam quanto ao unilateralismo da doutrina normativista no determinar o objeto da ciência do direito, consentese, todavia, em que o jurisconsulto há de atentar, como momento culminante da sua atividade, para a norma jurídica ou para o complexo normativo. Está implicito, nessa doutrina, que não cabe à ciência do direito criar a norma iurídica, se bem que lhe compita, diante dos elementos axiológicos que integram a estrutura do direito positivo, a explicitação do sentido que às proposições normativas são imanentes. No desenvolver ou explicar o sentido da norma, em face do momento axiológico, é natural que o jurista se deixe seduzir, contudo, pela tentação de modificar-lhe o conteúdo, transmudando-se, então, de fato, em criador do direito. A medida em que tudo isso pode acontecer é revelada, de modo eloqüente, pelas modernas doutrinas, acerca da hermenêutica jurídica, onde se sustenta que a interpretação começa por um juizo de valor a respeito da solução que merece a hipótese em exame. Significa isso que o fundamental, na exegese do direito, a teor dessa doutrina, é o momento axiológico, que, impondo-se à inteligência da norma, dá lugar, no fundo, à insuflação nela de sentido novo, se o aceito até então não se coadunar com as exigências deontológicas, que o caso concreto suscite.

Examinando, longamente, na obra citada, a ordem jurídica, também, na 
perspectiva filosófica, registra o saudoso ministro Leitão de Abreu, em certo passo:

O tratamento filosófico dos problemas jurídicos implica, pois, atitude, na qual se julga se o direito positivo corresponde, ou não, ao arquétipo ou modelo, a que se deve ajustar. Se a discrepância entre a idéia do direito e aquilo que o direito é na sua positividade ou facticidade torna insuportável a ordem juridica em vigor, haverá lugar para que se the negue validade. Não se limita, porém, a apreciação filosófica a essa manifestação de caráter negativo. Definida, em proporções deontológicas, a feição que se deve imprimir ao direito positivo, cumpre ao jurista, enquanto filósofo, apostar-se na transformação deste, a fim de aproximar, pelos meios ao seu alcance, a ordem jurídica dos valores a que esta deve subordinar-se. Se não é possivel, vor meios lógicos, passar do ser para o dever ser, da realidade para o valor, é possivel, contudo, referir o ser aos valores e promover, pela atração que o valioso exerce sobre o existente, a compatibilidade de um com o outro.

Reveste-se, desse modo, de importância científica a obra de João Leitão de Abreu sobre $A$ Validade da Ordem Jurídica, notadamente, pelo tratamento dispensado a matérias como o controle em abstrato da constitucionalidade das leis e a eficácia da norma inválida, o princípio da efetividade, a operatividade do fato na criação do direito e a teoria do fato normativo, bem assim o amplo estudo acerca das doutrinas da "jurisprudência analítica", da "jurispru- dência sociológica" e da "jurisprudência sobre as teorias da justiça", a par de outras questões teóricas da maior significação no estágio presente da ciência do direito. A atualidade dessa obra esgotada está a indicar a inequívoca conveniência de uma nova edição, ao ensejo de seu $35^{\circ}$ aniversário, ocorrido neste ano, para torná-la, de tal maneira, acessível aos estudiosos da teoria do direito.

Em 1976, o ministro Leitão de Abreu publicou, ainda, valioso e erudito ensaio sobre "Lei Natural e Lei Jurídica", inserido no livro Estudos de Direito Público em Homenagem a Aliomar Baleeiro, onde retoma o exame de algumas questões versadas em $A$ Validade da Ordem Jurídica.

11. A visão segura da política e do constitucionalismo moderno de Leitão de Abreu está, também, expressa em reflexões significativas e de densidade conceitual em dois outros importantes ensaios. O primeiro, publicado em janeiro de 1969, sob o título $A$ Crise da Constituição, onde examinou a realidade européia pós-guerra e, em especial, a Carta francesa de 1958, acentuado:

A crise constitucional que assinala os tempos modernos, como decorrência das transformações sociais ora em pleno desenvolvimento, é particularmente aguda naquilo que entende com a posição do Poder Legislativo entre os órgãos do Estado. A sua antiga e incontestável preeminência, como fonte de toda a autoridade, cede o passo, de modo sempre mais acentuado, à preeminência do Poder 
Executivo, diante da concentração de atribuições que se lhe deferem para desempenhar as tarefas capitais do governo.

\section{E acrescenta:}

A crise constitucional, que se abate sobre o universo político, nada mais é do que um dos aspectos ou reflexos $d a$ crise das idéias, que aflige, no seu conjunto, o universo cultural. A perplexidade que atormenta o espírito humano, diante do caráter problemático assumido, em todos os setores, por doutrinas e teorias, que se afiguravam diáfanas, certas $e$ inabaláveis, assalta igualmente a inteligência prática dos políticos e iuristas, diante da rebelião dos fatos contra esquemas e categorias constitucionais, que se reputavam definitivos, visto corresponderem a ditados da própria razão. A crise da Constituição, que esse estado de perplexidade revela, não resulta, entretanto, unicamente, dos escombros a que foi reduzida a antiga ordem constitucional. $O$ núcleo verdadeiro da crise está em que não se cristalizaram ainda principios novos que se substituam aos velhos postulados constitucionais.

O outro estudo, de 1978, elaborouse em torno da Constituição dos Estados Unidos da América do Norte de 1778, então comemorando seu bicentenário. Em análise rica de informações e reflexões, apreciou a origem, as crises institucionais superadas, o poder de emenda, a interpretação da Corte Suprema, a iudicial review, as transformações do direito constitucional americano, as conseqüências da I Guerra Mundial, as constituições da Europa, o controle concentrado de constitucionalidade das leis e o sistema americano com sua feição interpretativa peculiar, suas vinculações ao espírito do common law, a noção da recta ratio judicial, que se invoca como critério de razoabilidade da norma. Registrou, nesse erudito ensaio, o ministro Leitão de Abreu:

A história do venerável documento, que rege a vida política norteamericana, longe de possuir a placidez, que a sua duração poderá sugerir, é pontilhada de angústias, perigos e querelas. A sua história, em suma, é uma história de crises; e precisamente na virtude que exibe para dominar crises está a sua grande, a sua inapreciável contribuição para o constitucionalismo, mormente o contemporâneo que vê na judicial review fórmula impreterível para garantir ao sistema constitucional a estabilidade que dele se requer.

12. Evidenciam, de outra parte, a correspondência da ação do ministro Leitão de Abreu, como juiz, as linhas de seu pensamento, votos que proferiu no Supremo Tribunal Federal, tão bem registrados nas palavras do então advogado José Paulo Supúlveda Pertence, hoje ilustre ministro daquela Corte, na homenagem de despedida, por motivo de sua aposentadoria, em sessão de 30 de setembro de 1981:

"Recordem-se os seus votos a respeito da inviolabilidade parlamentar, ainda na 
vigência da redação original do art. 32 da Carta de 69, que assegurando-a nominalmente, dela excluía, no entanto, além dos crimes contra a segurança nacional, as acusações de calúnia, injúria e difamação. Quer ao sustentar a irresponsabilidade penal de um congressista por ofensa a outro, que "não transcenderia do âmbito das questões interna corporis do Parlamento, resolúveis dentro dos seus muros, por via disciplinar" (Apn 222) quer ao rejeitar denúncia contra deputado acusado de ofensa a autoridades administrativas, que traduziriam "opinião manifestada por parlamentar no desempenho de função inerente ao mandato" (Apn 240), lutou, com brilho e pertinácia excepcionais, o ministro Leitão de Abreu: tentou contra a confessada clareza da norma, que se reduzisse a exceção "aos limites mais rigorosos que o texto constitucional, explicado liberalmente, possa admitir, para evitar que a regra da imunidade, solenemente garantida, se convertesse - dizia - no que já se chamou a sombra de uma sombra, pois que, dessa prerrogativa constitucional, em última análise, pouco mais sobraria do que o galanteio de homenagem puramente verbal."

$\mathrm{Na}$ mesma linha das liberdades políticas, tornou-se célebre a sua manifestação, igualmente minoritária, pela inconstitucionalidade da LC 5/70, no ponto em que faz inelegível não só o condenado, mas o cidadão apenas denunciado por determinados crimes. O voto, de impressionante grandeza, extraí, da norma que assegura, além dos especificados, os direitos e garantias implícitos nos princípios do regime, a consagração positiva da presunção de inocência, nos termos da Declaração Universal dos Direitos do Homem, para daí deduzir a ilegitimidade constitucional da lei questionada. Responde à contradita de que a presunção de inocência estaria desmentida pela admissão da prisão provisória que "não vale argumentar com normas do direito comum para estabelecer limites a princípios fundamentais." "Em lugar de argumentar da lei ordinária para a norma fundamental, a fim de limitar-lhe o sentido e a eficácia" - redargue - "o que cumpre é argumentar dos princípios estabelecidos na declaração de direitos para os preceitos de lei ordinária, para subordinar estes últimos aos primeiros".

O mesmo raciocínio - da prevalência da substância e da força de expansão dos princípios fundamentais de segurança da liberdade - retorna, mais ou menos explicitamente, em numerosos votos seus. Particularmente naqueles em que, versando questões aparentemente rotineiras de processo penal comum, o ministro Leitão de Abreu prestou testemunho de aguda sensibilidade para a democratização dos direitos humanos, fazendo-os descer dos páramos dos direitos políticos para a planície da violência cotidiana da repressão penal comum sobre o homem indefeso das multidões anônimas.

Os exemplos seriam incontáveis. Recorde-se o papel decisivo do nosso homenageado, aqui vitorioso, na interpretação da L. 5.941, para firmar como direito subjetivo, não como mero arbítrio do juiz, a liberdade provisória do réu primário e de bons antecedentes. 
Releia-se o seu voto vencido pela extensão do direito de apelar em liberdade ao réu anteriormente preso em flagrante ou preventivamente, quando não subsistam, à sentença condenatória, motivos que imponham a manutenção do encarceramento (RHC 53.603). É, sem favor, um trabalho magistral - dificilmente superável no direito brasileiro - seja a respeito do caráter estritamente cautelar de todas as modalidades de prisão provisória, seja no tocante à natureza restrita do poder discricionário da autoridade judicial, insuscetível de equiparação ao conferido à autoridade administrativa.

$\mathrm{Na}$ mesma área, e com o mesmo sentido profundamente liberal que identificou a sua judicatura, refiram-se ainda - sempre derivados do princípio constitucional da ampla defesa, contra textos legais de sabor restritivo -, os votos do ministro Leitão de Abreu, sobre o caráter absoluto da nuiidade oriunda da ausência do réu preso à instrução do processo (HC 54.543); ou sobre a obrigatoriedade, para o defensor dativo, da apelação contra sentença condenatória (RHC 57.091), orientação depois alterada pela maioria do eg. plenário.

Na mesma oportunidade, o ministro Rafael Mayer, falando em nome da Corte, observou: Momentos da atividade judicante devem ser ressaltados, exponenciais de sua arte de julgar, caracterizados sempre pelo equilíbrio e segurança, e pelo suporte cultural, mas também registráveis pela marcante $\mathrm{e}$ definida posição a respeito de temas de singular relevo no direito aplicado.
Dedicado e exato, no exame de todos os casos a seu encargo, acrescem sempre os seus cuidados de juiz, quando os temas tocavam os magnos postulados de ordem constitucional, maiores dentre os magnos temas desta Casa.

São decerto destacáveis, como expressões de alta doutrina, alguns dos seus votos, em memoráveis julgamentos da Corte, no período em que se cumpriu a sua judicatura, temas que são representativos dessa linha de preocupações e de teses que emergem harmo-nicamente do sedimento de sua ciência jurídica.

Contribuição erudita, como a qualificou o eminente ministro Thompson Flores, está, por exemplo, no voto do ministro Leitão de Abreu, proferido nos debates em torno do conceito de ato do governo local, para o pressuposto do recurso extraordinário pela letra "c", a saber se compreensivo tão-somente dos atos normativos e não dos individuais. Em análise comparativa com símile norte-americano, concluiu pela abrangência maior do conceito brasileiro, mas afastando, de modo flexível a obrigatoriedade de conhecimento que é inerente a essa via recursal, "quando se tratar de ato individual cuja prática não ponha em risco, de modo significativo, a preeminência do Direito federal. (RE 80.896).

Ao declarar-se a inconstitucionalidade de lei regulamentadora da profissão de corretores de imóveis, o seu voto enfocou, de modo singular, o critério de razoabilidade a utilizar na hermenêutica do direito constitucional, para 
aferir se a lei ordinária "se manteve dentro de limites próprios, conve-nientes ou apropriados ao fim que teve em vista a Carta Política." Sob pena de constituir letra morta o direito individual ao livre exercício da profissão, os re-quisitos que o legislador the ponha devem ser compatíveis com o critério de razoabilidade, contrariado, no caso, de modo invalidante $\left(\mathrm{Rp} \mathrm{n}^{\circ} 930\right)$ com o que dava destaque a um critério prestante.

Apenas chegado a esta Corte, o ilustre ministro, com a clarividência de abordagem dos temas constitucionais e de direito administrativo, contribuiu com o seu voto, de maneira decisiva, para o deslinde de questão, que vinha debatida, de há muito, a que diz respeito a imunidade tributária do IBC no tocante às operações de revenda do café adquirido aos produtores. Ressalta, desse voto, de larga erudição, o rigor lógico em estabelecer a fina e precisa discriminação entre finalidade essencial e não essencial dos entes menores, índice da imunidade recíproca que lhes é extensiva pelo texto constitucional (MS 19.097).

Em se tornando relator, na Representação $n^{\circ} 921$, o ministro Leitão de Abreu, enfatiza um dos temas de sua predileção, o da hermenêutica constitucional, para tirar a consequiência do decisum. É que, invocando precedentes do corpus juris secundum, entendeu que, embora não vinculantes da Corte a interpretação administrativa ou judiciária precedente, cumpre, na determinação do sentido de uma norma ambígua, recorrer a subsídio de caráter extrínseco consistente na averiguação da exegese de tal norma dada ao tempo de sua adoção, e daí por diante, por aqueles cujo dever tem sido de interpretá-la, executá-la e aplicá-la na prática, cabendo emprestar-lhe grande peso ( $R p$ 921).

Deteve-se, demoradamente, nos conceitos constitucionais do direito tributário, numa pertinente e completa distinção entre taxa e contribuições especiais, postas em face dos elementos conotativos do imposto. Nessa análise dos dados configurantes da taxa florestal do Estado de Minas Gerais, permitiu que os identificasse com o fato gerador do ICM, o que fez o Tribunal, seguindo o seu entendimento, declarar-lhe a inconstitucionalidade (RE 78.600).

Como bem anotou o eminente ministro Rafael Mayer, "esse registro, como um perfil, contém apenas alguns índices representativos da escala de sua atividade judicante, impossível de condensar, na oportunidade, quer pelo número das manifestações, quer pela diversidade das proposições", acrescentando:

"Possível, no entanto, é obter, pela análise do seu trabalho de sete anos, nesta Corte, a confirmação e a consequiência dos conceitos e valores pelos quais, culturalmente, se guiou e formou, agora aprofundados e desdobrados a uma nova luz, ao crivo desse grave encargo de julgar. Em seus votos, na verdade, repercutem, ao revérbero dos fatos e das situações concretas, os princípios cristalizados de sua experiência jurídica, sob nova dimensão." 
E conclui:

"Assim, ao longo das formulações de uma cultura solidamente construída, de um seguro raciocínio silogisticamente discorrido, de ampla apreensão intelectual do complexo mundo das realidades, das normas e dos valores, nos sucessivos planos de sua atividade intelectual e jurídica, o ministro Leitão de Abreu realiza aquela coerência das diversidades no todo de um universo intelectual e moral, aquela unidade espiritual e dinâmica, que faz a marca indelével de uma presença."

O ministro João Leitão de Abreu foi, em vida, agraciado com todas as condecorações do Poder Executivo e do Poder Judiciário da República, inclusive a Ordem Nacional do Mérito, no grau "Grã Cruz", e com a mais alta insígnia de seu Estado natal, a comenda "Ponche Verde", bem assim com medaIhas e condecorações de Estados da Federação e de governos de nações amigas.

Em 1943, ainda estudante de Direito, João Leitão de Abreu casou com sua prima, D. Iracema Pessoa de Abreu. Nasceram dessa união feliz, que viu quase meio século passar, quatro filhas: Corina, Patrícia, Alice e Paula.

$\mathrm{Na}$ simplicidade de sua vida, austera e honrada, de inexcedível espírito público e amor ao bem comum, vocação constante ao serviço generoso, João Leitão de Abreu soube, admiravelmente, decifrar o enigma do poder, entendendo-o sempre, e assim o exercendo, não como um direito, que se atribua a alguém, mas como um instrumento posto a um fim que toca imediatamente ao serviço de todos. Nunca o atormentou a ambição do poder; jamais o seduziu o fascínio da riqueza. Nele não havia a tentação do parecer simplesmente, sem a responsabilidade do ser.

Sua morte, a 13 de novembro de 1992, entristeceu a Nação, quanto a sua amantíssima e dedicada família e a seus amigos. Os meios de comunicação reservaram-lhe significativos espaços $\mathrm{e}$ o chefe de Estado decretou luto oficial, numa justa homenagem de reverência a quem, no Executivo e no Judiciário, por longos anos, soube viver, com absoluta integridade, o verdadeiro mistério do poder, cuja essência deve ser o amor, a dádiva generosa de si, ao serviço de todos, sem outra lei que não a da bondade.

Estou certo de que sua vida há de ser lembrada pelos pósteros, com justiça, - conforme hoje já o faz esta Faculdade, nas comemorações de seu centenário -, como chefe de família exemplar, homem público integérrimo, professor, pensador e insigne magistrado, mas, acima de tudo isso, pela verdadeira bondade que, de fato, informava todos os seus gestos e inspirava o pensamento mesmo, pois é pela bondade que o homem se faz mais chegado à sabedoria, mais voltado para a eternidade que para o tempo. 